Article

\title{
Loanwords for Language Learners: Help or Hindrance?
}

\author{
Kaori Nakao \\ Kyushu Sangyo University \\ doi: http://dx.doi.org/10.7820/vli.v05.1.nakao
}

\begin{abstract}
Background: Loanwords are a growing component of the Japanese language. During the past six decades, the majority of new loanwords entering the Japanese language have come from the English language. For native Japanese speaking students, loanwords are a source of potential frustration and support, both within their L1 and L2 (English).

Aims: To explore and further our understanding of students' knowledge of high frequency loanwords.

Sample: One hundred thirty undergraduate students of mixed major, studying in a compulsory course (Eigo/Eigokaiwa), at Kyushu Sangyo University, participated in this exploratory study.

Methods: This study compares loanword self-reported difficulty (L2) with students' productive knowledge in their L1. This study was undertaken with a group of first- and second-year students $(n=130)$ enrolled in compulsory English classes.

Results: For half of the loanwords examined, self-reported difficulty and students' productive knowledge was consistent. The remaining words examined were inconsistent with self-report measures, generally underestimating students' actual productive knowledge.

Conclusions: Error analyses of students' L1 sentences indicated that inconsistencies observed between self-report and productive knowledge may be due to students' partial knowledge of words expressed through their reliance on katakana translations of the words tested. Implications for practice and future directions are discussed.
\end{abstract}

\section{Introduction}

Japanese learners of English must learn many English words that are loanwords in their L1. It may be the case that loanword knowledge helps students to learn a new language (Gass, 1996; Odlin, 1989, 2003). Due to the large number of English loanwords in the Japanese language, loanword knowledge might be particularly important for Japanese students of English. For this reason, it is important that the link between loanwords and English vocabulary acquisition is explored with Japanese learners of English.

The relative difficulty of learning similar versus dissimilar words across L1 and L2 has been extensively researched (de Groot, 2006; Ellis \& Beaton, 1993). Ellis and Beaton (1993) found that phonological congruence between an L2 target lexical item and the L1 translation had a major influence on potential L2 vocabulary acquisition. 
Consistent with this finding, de Groot (2006) concluded that, "words with a 'cognate' translation in the FL [Foreign Language] ... were learned far better than those with a noncognate translation" (Schmitt, 2010, p. 72). Schmitt (2010) suggested that this effect is due to both the relative similarity/dissimilarity of the words in L1 and L2, and the way those words are processed. Morphological congruency between L1 and L2 vocabulary can make lexical items easier to learn (Schmitt, 2010). It essential therefore that teachers and course designers attend to the similarities and patterns between students' FL and the second language under study in order to encourage adaptive language acquisition (Nation, 1990). While Daulton (2011) examined university students' attitudes towards loanwords, this study did not examine students' knowledge of loanwords. As a result, it is still not clear empirically what the effect of loanword status is on students' L2 vocabulary acquisition. In addition, there has been no study to date that has tried to compare and examine student's cognate knowledge of vocabulary with their productive knowledge.

Following a review of the literature, this article will present results comparing the pattern of relationship between self-reported difficulty of loanwords and students L2 understanding of these words.

\section{Literature Review}

\subsection{History of Loanwords Gairaigo Within L1}

Although the country of Japan has never experienced a large immigration of people since the Japanese first settled the country, the Japanese language has undergone a sustained influx of foreign words. The first examples of this influx began early in Japanese history in the fourth century, when Japan borrowed Chinese characters (kanji) from China. In the sixth century - at the beginning of the Heian period - these borrowed characters were used as a foundation for creating the original Japanese phonetic scripts hiragana and katakana. The first vocabulary to come from the West arrived in the sixteenth century when the Portuguese and Dutch languages came with European explorers, and the influx continued with increasing trade. The next major inflow of foreign words coincided with the Meiji Restoration (nineteenth century), during which Japan underwent rapid modernization. During the Meiji Restoration, many aspects of Western culture were adopted, and the primary source of new borrowed language was English. While words of Chinese origin are loanwords in a restricted sense, the current research, undertaken in a globalized world, focuses on loanwords that are used in katakana today and are primarily of English language origin. The globalization of Japan has coincided with dramatic changes to the Japanese language. Specifically, during the past five decades, the number of English loanwords incorporated into the Japanese language has rapidly increased. In 1964, the National Institute for Japanese Language (NIJLA) undertook a lexical analysis of the kind of Japanese language employed in 90 magazines for one year (in 1956). The results indicated that in 1956, only $9.8 \%$ of magazine text was composed of loanwords, whereas in 1994, 33.8\% of similar magazine text consisted of loanwords (NIJLA, 2005). These results indicate that loanword use in Japan has steadily increased since the 1960s and can almost certainly be expected to continue to increase in the future. 


\subsection{Loanword L2 Issues and Attempted Solutions}

While loanwords are powerful tools for enriching Japanese language expressions, these new words also cause considerable confusion for some FL speakers (NIJLA, 2006). Acknowledging the difficulty loanwords cause, NIJLA has suggested that the difficulty of some loanwords is a very real problem for some native speakers of Japanese, as the government and newspapers have been careless in their use of loanwords, therefore causing considerable confusion for L1 speakers (NIJLA, 2006). As a result of this trend, NIJLA initiated the Gairaigo iinkai (loanwords committee) in August, 2002, and then four times between 2003 and 2006. Based on these Gairaigo iinkai, the NIJLA proposed that 176 loanwords be restated in the original Japanese (hiraganalkanji) terms in order to reduce confusion for Japanese language speakers. For example, “accountability” (アカウンタビリティー) has a clear original Japanese (hiraganalkanji) definition, setsumei sekinin (説明責任). Similarly, the loanword "access" (アクセス) has three separate (hiraganalkanji) definitions: (1) setsuzoku (接続), (2) kotsu shudan (交通手段), and (3) sannyu (参入).

In a recent article, Asahi Newspaper (2013) reported on an example of the growing use and potential confusion caused by loanwords for L1 speakers of Japanese. In this newspaper article, a 71-year-old man filed a lawsuit against a national television broadcaster, Nippon Housou Kyoukai/Japan Broadcasting Corporation (NHK). In his lawsuit, he demanded that NHK assume responsibility for the emotional distress caused by excessive use of loanword on television: for example, kea (ケア “care”), risuku (リスク “risk”), and toraburu (トラブル “trouble”) (Asahi Newspaper, 2013/6/26). The claimant asked the National Television station not to use such loanwords unless absolutely necessary. With so many loanwords in the Japanese language (48,100 loanwords are included in the Concise Dictionary of Katakana Words) and increasing rapidly, elderly people who are not used to using these words, but see and hear them in newspaper and on the television, are clearly having trouble understanding the meaning of some words (NIJLA, 2006).

\subsection{The Current Study}

Within this exploration, the difficulty of target vocabulary is an important component. The difficulty of the target learned language is generally considered to be strongly related to the acquisition and effective utilization of vocabulary knowledge.

It might be the case that loanwords play a crucial role in English language acquisition for native speakers of Japanese. Second-language researchers agree that vocabulary acquisition is an essential part of language learning, both for low- and high-proficiency students (Grabe, 1991; Laufer \& Nation, 1999; Nation, 1990; Schmitt, 2000). Knowledge of the top 2,000 headwords is sufficient for a learner to read and understand more than $80 \%$ of the words of any given text (Nation, 1990) many of which are loanwords (Daulton, 2008).

While Nation has noted that loanword knowledge may assist in language acquisition, empirical research has consistently indicated that some Japanese language speakers have inconsistent knowledge of loanwords (Daulton, 2008). For Japanese students learning English, there are several ways in which loanword knowledge may also impede language acquisition. Uchida's (2001) review of the 
literature suggests that when English words enter into the Japanese language, the words' phonetics, morphology and semantics often change. When English words become a loanword within the Japanese language, they undergo a range of potential adaptations. Adaptations may include phonological, orthographical and semantic shifts. For example, "strike" (su-to-ra-i-ki) has changed from one syllabic sound to five - that is, proparalepsis. Furthermore, "strike" has two meanings in Japanese, one is original “ストライキ” (meaning) and “ストライク” is a baseball term. In this way, loanwords may inhibit the processing and acquisition of some English vocabulary. For example, two English words "glove" and "globe" are both represented as guroobu (グローブ) in Japanese, which might confuse second/foreign language learners as these words' orthography is the same in katakana (Japanese).

Despite the long history of loanwords within the Japanese language and potential difficulties loanwords might cause Japanese students of English, scant research has been carried out in this area of language learning. Research that has been carried out has often taken the form of content analysis of existing Japanese text (e.g., NILJ, 1964) or the use of yes/no checklists (Gibson \& Stewart, 2011). Content analyses have informed us about the growth and nature of loanwords in the Japanese language, and checklist research has suggested that these words may be easy due to their loanword status (Gibson \& Stewart, 2011). Despite these advances, the validity of checklist data is still in question (Stubbe, 2012), and the productive knowledge and use of loanwords by Japanese learners of English is poorly understood. By examining the relationship between productive L1 knowledge of loanwords, relative to word difficulty - selfreported difficulty determined with large sample checklists - the current study aims to contribute to this field. In addition to the theoretical contribution of this research, there are clear practical implications for exploring the relationship between lexical knowledge and loanword status. Preliminary results from an ongoing content analysis of KSU's first- and second-year wordlist, employing past British National Corpus (BNC) analysis (Nation, 2004) and the Concise Dictionary of Katakana Words (Sanseido, 2010), suggest that a large (74\%) percentage of words taught are loanwords. It may be that some Japanese learners of English, especially beginners, learn more directly from katakana than English to start. This is consistent with research that has indicated that L1 exerts a considerable effect on the learning of L2 vocabulary (Ellis, 1997; de Groot, 2006; Schmitt, 2010). Particularly, L2 words that match L1 orthographical and phonological patterns are easier to learn (de Groot, 2006). Daulton (2010) studied correspondences of the 3000 word families of the BNC to common Japanese loanwords by frequency level, concluding that "in $54.8 \%$ of word families [of the first 1000 most frequent words], one or more members corresponded to verified Japanese loanwords."

Due to the very close connection between L2 $1 \mathrm{~K}$ words and students' L1, it is essential that we examine the vocabulary knowledge of students who are learning English vocabulary at the $1 \mathrm{~K}$ level to explore the effect of loanwords on English vocabulary learning and knowledge. It is therefore important to examine the link between loanwords and English vocabulary acquisition with Japanese students learning English.

This exploration should employ the wealth of research already undertaken to assess word difficulty through self-report measures in conjunction with an objective measure of students' productive vocabulary knowledge of the same words (Gibson \& Stewart, 2011). Because assessing beginner students' productive L2 knowledge is necessarily problematic and due to potential concerns highlighted in the literature 
review regarding L1 comprehension of loanwords, L2 productive knowledge should be employed. This research will provide insight into self-reported knowledge and related word difficulty by examining students' L1 productive knowledge. This research will also offer teachers a sense of both the barrier and benefit that loanwords can be for beginner Japanese EFL students.

\section{Aims}

This study has two aims: (1) to compare Japanese students' self-reported knowledge of the meaning of English loan words with their knowledge, as observed on objective productive vocabulary test, and (2) to qualitatively examine students L1 use of high-frequency English loanwords.

\section{Methods}

\subsection{Sample}

One hundred thirty undergraduate students of mixed major, studying in a compulsory course (Eigo/Eigokaiwa), at Kyushu Sangyo University, participated in this exploratory study.

\subsection{Procedure}

In a prior study, Gibson and Stewart (2011) explored the self-reported difficulty of 900 of the first 2000 most frequent words of English, based on the Longman English corpus employed in the Longman English-Japanese Dictionary (Bullon, 2007). Self-reported difficulty data were collected through yes/no checklists ( $n=2768$ ), with multiple forms using anchor items to connect the test forms under the Rasch model (Linacre, 2013). Word difficulty was calculated using the Rasch logit difficulty measure taken from the collective student responses regarding their self-reported vocabulary knowledge.

For the current study, students were asked to write one English and one Japanese sentence for 10 loanwords selected from a prior curriculum-wide test. The words for this test were selected from the top 2000 high-frequency words. The task took between 8 and 15 minutes for students to complete.

The instructions that prefaced the test asked the participants to write one English and one Japanese sentence for each of the 10 loanwords listed. Students were encouraged to try to write a sentence for all words.

\subsection{Analysis}

Japanese translations of target vocabulary were coded into incorrect and correct. Correct translations were then coded based on hiraganalkanji or katakana usage. Sentences were coded based on sentence structure: just the word, a subjectverb sentence employing the word, and more than a subject-verb sentence employing the word. Table 1 presents coding employed in the current study. 
Table 1. Coding for Japanese and English Vocabulary Examined

\begin{tabular}{llclc}
\hline Definition & Writing type & Score & Sentence level & Score \\
\hline Incorrect & & 0 & Word & 1 \\
Correct & Hiragana/kanji & 1 & $\mathrm{~S}+\mathrm{V}$ & 2 \\
& Katakana & 2 & More than S $+\mathrm{V}$ & 3 \\
\hline
\end{tabular}

Categories were graphed with difficulty data for each word. Graphs were then employed to compare the self-reported difficulty and students' productive L1 knowledge of the words.

\section{Results}

The results of this study are presented in the following order. First, the pattern of difficulty and productive knowledge is presented. Second, an error analysis of students' answers is presented. Finally, three questions arising from the pattern of students' comprehension of the Japanese meaning and the word's difficulty are presented.

\subsection{Pattern of Difficulty and Productive Knowledge}

Students' productive knowledge of 4 ("master," "limit," "version," and "tool") out of the 10 target loanwords was consistent with the words' self-reported difficulty (Figure 1). From "roll" to "battery," there is a slow increase in productive difficulty but a slow decrease in self-reported knowledge. "Paragraph" and "cash" was the exception to this trend. Students indicated that "paragraph" was the most

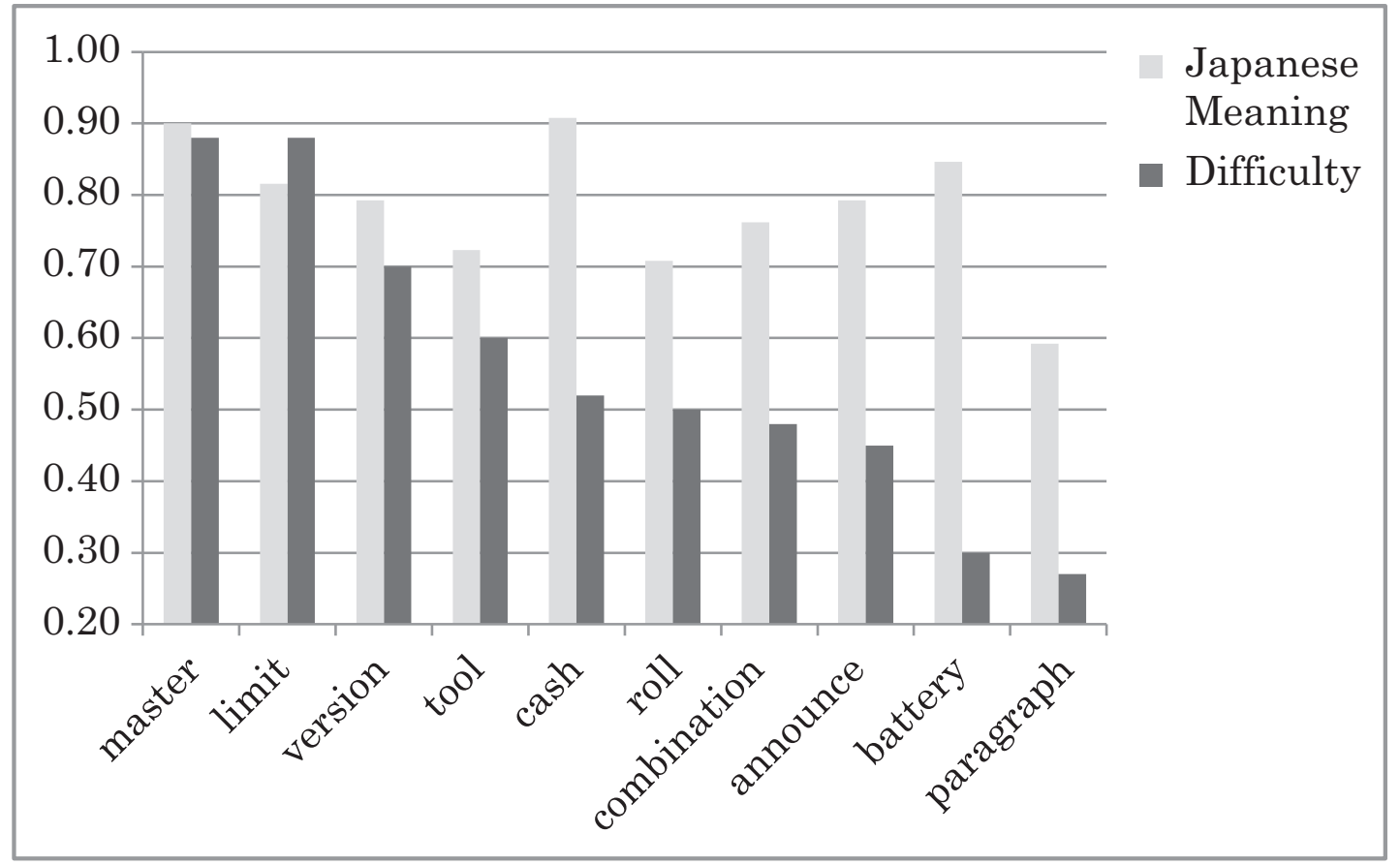

Figure 1. Self-reported Difficulty Represented by Percentage and Productive Word Knowledge (Japanese Meaning) Represented by Percent of Correct Productive Use of the Word in a Japanese Sentence. 
difficult item of the 10 tested, while "cash" was reported as being far more difficult than productive Japanese knowledge results indicated.

The considerable gap in students' self-reported productive knowledge of the final five words presented in Figure 1 suggested that some aspect of these words was either inflating students' productive knowledge or reducing their self-reported knowledge. One potential explanation for this misalignment is that over half $(52 \%)$ of students" use of "combination" and $60 \%$ of student's use of "battery" in Japanese were as katakana rather than the original hiraganalkanji usage. This result indicates that while students may not be confident in their knowledge of a words' meaning, they have a sense of the word's katakana usage. For example, for the word "combination," students generally used konbilkonbineeshon rather than kumiawase or suuji[moji]no kumiawase (組み合わせ，数字[文字]の組み合わせ), which, based on the Longman English-Japanese Dictionary's Japanese frequency corpus, are the two most common definitions of "combination." For "battery," students generally used batterii rather than denchi (電池) in their productive use of the word. The results suggest that many students' knowledge of "combination" might be restricted to the katakana definition. Similarly, the inconsistency between students' productive knowledge and the self-reported difficulty "announce" might be attributed partially to katakana use $(30 \%)$. Furthermore, in Japanese, "announce" has a range of meanings, which allow for flexible productive use in Japanese. Katakana is generally fixed to one meaning of the word, therefore narrowing its meaning. For example, "battery" has multiple meanings in English and one of those meaning is a baseball term (e.g., pitcher and catcher partner for practice. 彼とバッテリーを組む (Kare to batterii wo kumu) meaning "I pair with him in a baseball game.").

\subsection{Common Mistakes Resulting from Shared Katakana Phonology}

Seventy percent of students reporting Japanese definition of "roll" were correct. Seventeen percent of students, however, reported 役割を果たす (yakuwari wo hatasu) meaning "role"; these two words share the same katakana as ロール (rooru).

Seventy-three percent of students reporting Japanese definition of "tool" were correct. Nine percent of students, however, reported 背が高い (se ga takai), which means "tall." It is reasonable to assume that this type of error may be due to students thinking in katakana and therefore miss-decoding the word.

\section{Students' Error Analysis}

One type of error many students made in their use of the 10 words in productive sentences was phonological errors. For example, when students were instructed to employ "tool" in a sentence, some students used the word “背が高い (se ga takai)," which means "tall." Two examples of students' errors were

Student 1: I am tooler than you.

Student 2: I'm the toolest [in the] class No.1. 
These sentences suggest that students are reading "tool" and then phonologically interpreting the word to be "tall."

A second source of errors for students were katakana words that had two meanings in Japanese. An example of such errors can be seen in students' use of the word "roll" in sentences; "roll" or "ロール (rooru)" in Japanese confused both lowand intermediate-proficiency students. Two examples of the kinds of errors students made are

Low—proficiency student: My roll is leader.

Intermediate - proficiency student: I played an important roll in a trip to Korea because I could speak Korean and English a little.

\section{Three Questions Based on the Pattern of Japanese Meaning and Word Difficulty}

An examination of Figure 1 raises three questions based on the pattern of Japanese meaning and word difficulty observed. First, "master," "limit,", "version," and "tool" were consistent with the words' self-reported difficulty. Second, from "role" to "battery" exhibited there was greater productive difficulty but a fewer self-reports of knowledge. For example, students employed katakana definitions $52 \%$ and $60 \%$ of the time for "combination" and "battery." Students' katakana usage focuses mostly on electronic equipment, such as cars and cell phone. Students generally talked about their cell phones in their Japanese sentences. When wishing to express that their cell phone batteries were dead or running out, students said “keitai no batterii ga kireta." (携帯のバッテリーが切れた "My cell phone's battery is dead.”) or “batterii ga sugu kireru.” (携帯のバッテリーがすぐ切 れる “My battery has been running out so fast.”). Students generally preferred to use batterii (バッテリー) over denchi (電池) for cell phone-related sentences. With regard to car-based sentences, "kuruma no batterii wo kokan suru hitsuyo ga aru." (車のバッテリーを交換する必要がある “I need to replace my car's battery.”) and “kuruma no batterii ga agatta.” (車のバッテリーが上がった “My car's battery has run out."). In some cases, students actually got the meaning wrong: for example, "keitai denwa no juden ga nakunaru." In this case, the student misinterpreted the meaning of battery, batterii (バッテリー “battery”) as Juden (充電 “charge”). Mistakes like this suggest that students may be indicating knowledge of words on the checklist which students have a sense of, but don't know concretely.

The two exceptions to the patterns observed between productive Japanese knowledge and self-reported knowledge, "cash" and "paragraph," bear some attempt at explanation. For "cash," students used the katakana translations (37\%) more often than genkin and shikin (現金, 資金 “cash”). One of the loanwords, kyasshu kaado (キャッシュカード “cash card”) was commonly used by students: for example, “kanojo wa kyasshu kaado wo tsukutta." (彼女はキャッシュカードを 使った “She used her cash card."; “Watashi wa kyasshu kaado wo motteimasu." (私 はキャッシュカードを持っています “I have a cash card.”). As mentioned above, "cash" is recognized as a proper name by some students. There were misinterpretations of "cash card" as "credit card"; for example, "If you use a cash card, you don't have to bring your money when you go shopping." If they recognize the 
"cash" word as proper name ("cash card") or misinterpret ("credit card"), when they see "cash" word there is the possibility that they not actually know the meaning. As for "paragraph," students knew the meaning 52\% of time, but about $30 \%$ of their use was in katakana form. Students generally used paragurahu(パラグ ラフ) rather than danraku (段落) in their Japanese sentences. As mentioned above, katakana use is not clear. The word "paragraph" is not used on a daily basis by students, perhaps only in their English class. Based on students' errors in using Japanese, such as $z u$ (図 “graph”) and shashin (写真 “photograph”), it may be that students more frequently use the word "paragraph" in katakana than the original Japanese. Clearly, katakana is also Japanese; however, it is not always true that students lack a full understanding of the loanword's meaning when they use it. When discussing loanword use with students, one student noted that

I guess the meanings of unknown loanwords from the context without asking someone the meaning who use the loanword or looking up the meanings of unfamiliar words. When I don't know the word, but I sometimes use in katakana if I have sense of the word.

This student's comment indicated that loanword use is flexible, even if students do not understand the meaning, they will be able to express the meaning of unknown loanwords in katakana. Clearly, the pattern and exceptions to the patterns remain a matter for further investigation.

\section{Conclusions and Future Directions}

Self-reported difficulty and productive knowledge were consistent for 4 of the 10 words tested. However, katakana knowledge may inflate students' self-reports of productive knowledge of some loanwords. For many students within the sample for this study, their knowledge of loanwords was often limited to the katakana translation, despite the meaning being of low frequency within the Japanese language.

Error analysis of students' Japanese sentences indicated that katakana knowledge may be interfering with students' interpretation of loanwords. Having a single katakana form for two loanwords, such as "ロール," may confuse both low- and high-proficiency students. This suggests that Japanese learners of English as a foreign language are experiencing a very specific type of interference: processing interference due to polysemy katakana words.

In the current study, only loanwords were included in the productive test of students' vocabulary knowledge; however, an even proportion of loanwords and non-loanwords should be included in future tests. Testing of loanwords with nonloanwords will enable future research to isolate vocabulary acquisition difficulties specific to loanwords.

The effect of students' field of study on their loanword knowledge and use may also be a fruitful avenue of investigation. It is possible that students in KSU departments such as Information Studies and Fine Arts interpret loanwords through the lens of their studies. For example, in current study, students in the department of Information Studies all translated "version" as “バージョン" (vaajyon) and employed the word in sentences describing software. Finally, it is important to test existing theories of loanword acquisition (e.g. Uchida, 2001) 
towards an empirically robust loanword theoretical framework. This might be undertaken by categorizing the loanwords within the top 2000 words of English into a theoretical framework such as that suggested by Uchida (2001). Self-reported difficulty of the same loanwords might then be used to validate the framework. Analyses could examine the amount of variance in difficulty explained by a loanword theoretical framework.

\section{Limitations}

Word classification was provided for each of the 10 words to ensure students understood what word to employ in their sentences on the productive test used in the current study. Instructions for the test, however, strongly encouraged students to attempt a sentence for all 10 words presented by the test. This situation may have played a role in students using the noun form of some words, when the verb form was stipulated by some questions.

\section{Acknowledgements}

I would like to thank Jeff Stewart for his detailed suggestions and support. I would also like to thank Aaron Gibson for his support and providing the word difficulty data for this research.

\section{References}

Asahi Newspaper. (2013, June 26). Too many loanwords. Put NHK before the court. p. 38.

Bullon, S. (Ed.). (2007). Longman English-Japanese dictionary. Edinburgh Gate: Pearson Education.

Daulton, F.E. (2008). Japan's built-in lexicon of English-based loanwords. Clevedon, UK: Multilingual Matters.

Daulton, F.E. (2010). High-frequency English-based loanword cognates for EFL in Japan. Asian Journal of English Language Teaching, 20, 65-88.

Daulton, F.E. (2011). On the origins of gairaigo bias: English learners' attitudes towards English-based loanwords in Japan. The Language Teacher, 35(6), $7-12$.

De Groot, A.M.B. (2006). Effects of stimulus characteristics and background music on foreign language vocabulary learning and forgetting. Language Learning, 56(3), 463-506. doi:10.1111/j.1467-9922.2006.00374.x

Ellis, N.C. (1997). Vocabulary acquisition: Word structure, collocation, grammar, and meaning. In M. McCarthy \& N. Schmidt (Eds.), Vocabulary: Description, acquisition and pedagogy (pp. 122-139). Cambridge: Cambridge University Press.

Ellis, N.C., \& Beaton, A. (1993). Psycholinguistic determinants of Foreign Language vocabulary learning. Language Learning 43, 559-617. doi:10.1111/ j.1467-1770.1993.tb00627.x 
Gass, S.M. (1996). Second language acquisition and linguistic theory: The role of language transfer. In W. Ritchie \& T. K.Bhatia (Eds.), Handbook of second language acquisition (pp. 317-345). San Diego, CA: Academic Press.

Gibson, A., \& Stewart, J. (2011). Using Yes/No tests to examine the relationship between frequency and difficulty in the vocabulary knowledge of second language learners. Kyushu Sangyo University Language Education and Research Center Journal, 6, 23-35.

Grabe, W. (1991). Current developments in second language reading research. TESOL Quarterly, 25, 375-406. doi:10.2307/3586977

Laufer, B., \& Nation, P. (1999). A vocabulary-size test of controlled productive ability. Language Testing, 16(1), 33-51. doi:10.1177/026553229901600103

Linacre, J.M. (2013). Winsteps [computer software]. Beaverton, Oregon: Winsteps. com., Retrieved from http://www.winsteps.com/

Nation, I.S.P. (1990). Teaching and learning vocabulary. Heinle and Heinle.

Nation, I.S.P. (2004). A study of the most frequency word families in the British National Corpus. In P. Bogaards \& B. Laufer (Eds.), Vocabulary in a second language: Selection, acquisition and testing. Amsterdam: John Benjamins.

National Institute for Japanese Language (NIJLA). (1964). Gendai zasshi kyuujusshu no yougoyouji (3) bunseki. Shuuei shuppan. Tokyo.

National Institute for Japanese Language (NIJLA). (2006). "Gairaigo" iikae teianwakarinikui gairaigo wo wakariyasuku surutame no kotoba zukai no kufu-dai ikkai dai yonkai soshuhen. Retrieved from http://www.ninjal.ac.jp/gairaigo/ Teian1_4/iikae_teian1_4.pdf

NIJLA (2005). Gendai zasshi no goichousa-1994 nen hakkou 70shi. NIJLA. Tokyo.

Odlin, T. (1989). Language transfer: Cross- linguistic influence in language learning. Cambridge, UK: Cambridge University Press.

Odlin, T. (2003). Cross-linguistic influence. In C. Doughty \& M. Long (Eds.), The handbook of second language acquisition (pp. 436-486). Oxford: Blackwell.

Sanseido. (2010). Concise dictionary of katakana words (4 ${ }^{\text {th }}$ ed.). Tokyo: Sanseido.

Schmitt, N. (2000). Vocabulary in language teaching. Cambridge: Cambridge University Press.

Schmitt, N. (2010). Researching vocabulary: A vocabulary research manual. Basingstoke: Palgrave Macmillan.

Stubbe, R. (2012). Do pseudoword false alarm rates and overestimation rates in Yes/No vocabulary tests change with Japanese university students' English ability levels? Language Testing, 29, 471-488. doi:10.1177/0265532211433033

Uchida, E. (2001). The use of cognate inferencing strategies by Japanese learners of English (Ph.D. dissertation). University of Essex, Essex. 